Jurnal Progres Ekonomi Pembangunan (JPEP)

Volume 5, Nomor 1. Tahun 2020

Page: $1-11$

http://ojs.uho.ac.id/index.php/JPEP

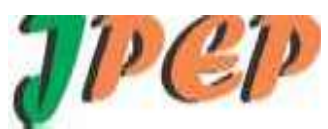

\title{
ANALISIS PENGARUH KEBIJAKAN FISKAL TERHADAP PERTUMBUHAN EKONOMI INDONESIA
}

\author{
Sem Rantebua \\ Program Ilmu Ekonomi Pascasarjana Universitas Halu Oleo Kendari \\ Email: semrantebua@gmail.com \\ Rosnawintang \\ Fakultas Ekonomi dan Bisnis Universitas Halu Oleo Kendari \\ Email: nanarosnawintang@yahoo.co.id \\ La Ode Suriadi \\ Fakultas Ekonomi dan Bisnis Universitas Halu Oleo Kendari \\ Email: ldsuriadi@gmail.com
}

\begin{abstract}
ABSTRAK
Fokus dari penelitian ini adalah menganalisis pengaruh kebijakan fiskal terhadap pertumbuhan ekonomi Indonesia, baik dalam jangka pendek maupun jangka panjang. Untuk mencapai tujuan tersebut dibangun model persamaan simultan dengan metode Error Correction Model (ECM).Data dikumpulkan dari berbagai sumber seperti Kementerian Keuangan, Bank Indonesia, dan Badan Pusat Statistik. Data tersebut menggunakan data time series per-triwulan dari tahun 2009 - 2018.

Hasil penelitian menunjukkan bahwa kebijakan fiskal yang diukur oleh penerimaan negara, belanja negara dan pembiayaan baik dalam jangka pendek maupun jangka panjang berpengaruh signifikan terhadap pertumbuhan ekonomi Indonesia.Dari hasil analisis variabel peneriman negara yang paling dominan dalam mempengaruhi pertumbuhan ekonomi Indonesia.Oleh karena itu pemerintah harus mengelola serta memaksimalkan potensi sumber-sumber penerimaan negara baik dari sektor pajak maupun sektor non pajak. Hasil penelitian ini mempertegas Teori Harrod - Domar yang menyatakan bahwa pentingnya pembentukan modal sebagai syarat utama untuk mencapai pertumbuhan ekonomi yang baik (steady growth).
\end{abstract}

Kata Kunci:Kebijakan Fiskal, Pertumbuhan Ekonomi, ECM

\section{ABSTRACT}

The focus of this study is to analyze the effect of fiscal policy on Indonesia's economic growth, both in the short and long term. To achieve these objectives a simultaneous equation model was built using the Error Correction Model (ECM) method. Data was collected from various sources such as the Ministry of Finance, Bank Indonesia, and the Central Statistics Agency. The data uses quarterly time series data from 2009 - 2018.

The results showed that fiscal policy measured by state revenue, state spending and financing both in the short and long term had a significant effect on Indonesia's economic growth. From the results of the analysis of the state's most dominant variable in influencing Indonesia's economic growth. Therefore the government must manage and maximize the potential sources of state revenue from both the tax and non-tax sectors. The results of this study reinforce the Harrod-Domar theory which states that the importance of capital formation is a key condition for achieving steady economic growth.

Keywords: Fiscal Policy, Economic Growth, ECM 
Jurnal Progres Ekonomi Pembangunan (JPEP)

Volume 5, Nomor 1. Tahun 2020

Page: $1-11$

http://ojs.uho.ac.id/index.php/JPEP

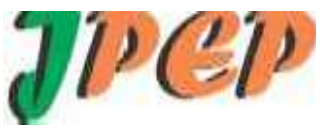

e-ISSN: 2052-5171

\section{PENDAHULUAN}

Pertumbuhan ekonomi yang baik adalah tujuan utama semua negara di dunia tak terkecuali di Indonesia. Pertumbuhan ekonomi akan selalu menjadi pusat perhatian dan menjadi salah satu isu yang banyak menyita perhatiant dunia, untuk mencapai tujuan tersebut harus diikuti dengan kemampuan variabel makro ekonomi dalam mengatasi setiap masalah ekonomi yang ada.

Secara umum terdapat beberapa permasalahan ekonomi makro, yaitu inflasi, tingkat output (PDB), penyerapan tenaga kerja dan neraca pembayaran atau balanceofpayment (BOP). Keempat permasalahan ekonomi makro tersebut dapat dipengaruhi oleh pemerintah, salah satunya melalui kebijakan fiskal.

Perkembangan ekonomi akhir-akhir ini menghidupkan kembali debat tentang efektivitas kebijakan pemerintah yang membawa kepada pertumbuhan ekonomi yang seimbang. Terdapat perbedaan interpretasi tentang bagaimana kebijakan makro ekonomi pemerintah dapat merespon stabilitas perekonomian. Teori Keynesmenyatakan bahwa pengeluaran pemerintah adalah komponen agregat yang mempengaruhi output tapi kebijakan moneter menyebabkan meluasnya ketidak efektifan, sementara itu teori monetaris menyatakan bahwa kebijakan moneter lebih efektif mempengaruhi output namun sebaliknya kebijakan fiskal tidak efektif (Belliveau, 2011).

Ekonom moneteris, dengan tokohnya Milton Friedman dan Edmund Phelps menyatakan bahwa kebijakan yang berorientasi permintaan akan tidak efektif, karena dalam jangka panjang output agregat indifferen terhadap harga sementara kebijakan moneter lebih efektif daripada kebijakan fiskal sepanjang kurva penawaran positif dalam jangka pendek. Di lain pihak, beberapa kaum fiskalis seperti J. Tobin dan P. Samuelson menyatakan bahwa kedua kebijakan moneter dan fiskal dapat mempertahankan kenaikan output nasional untuk periode yang cukup panjang, tapi kebijakan fiskal lebih efektif daripada kebijakan moneter (Topcu: 2012).

Mengingat fenomena tersebut sangat menarik untuk di kaji, oleh karena itu banyak peneliti yang telah melakukan studi yang serupa dengan penelitian ini diantaranya : Irfan/2015, Hoppner/ 2011, Olisaemeka/ 2018, Santoso /2009, Nawawidan Irawan/ 2011, Nainggolan /2010, Waluyo/2006, Gulo/ 2008, dan lain-lain.

Penelitian ini penting untuk dilakukan mengingat bahwa untuk mencapai suatu perekonomian yang baik diperlukan rumusan kebijakan makro ekonomi yang tepat, salah satunya melalui kebijakan fiskal. Oleh karena itu, penelitian ini di lakukan lebih intensif dengan menggunakan data variabel yang lebih kompleks guna melengkapi penelitian sebelumnya, dimana pengukuran kebijakan fiskal diambil dari total penerimaan negara, belanja negara, dan pembiayaan. Dengan demikian penelitian ini diharapkan dapat memberikan gambaran terkait dampak dari kebijakan fiskal terhadap pertumbuhan ekonomi di Indonesia, baik dalam jangka pendek maupun jangka panjang.

Sejalan dengan identifikasi masalah di atas maka penelitian ini bertujuan untuk menganalisis pengaruh kebijakan fiskal terhadap pertumbuhan ekonomi di Indonesia baik dalam jangka pendek maupun dalam jangka panjang. 
Jurnal Progres Ekonomi Pembangunan (JPEP)

Volume 5, Nomor 1. Tahun 2020

Page: $1-11$

http://ojs.uho.ac.id/index.php/JPEP

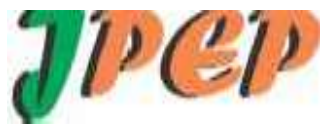

\section{KAJIAN PUSTAKA DAN KERANGKA KONSEP}

\section{Kebijakan Fiskal}

Kebijakan Fiskal adalah suatu kebijakan ekonomi dalam rangka mengarahkankondisi perekonomian untuk menjadi lebih baik dengan jalan mengubahpenerimaan dan pengeluaran pemerintah (Sukirno, 2003)

Tujuan umum dari kebijakan fiskal adalah mempengaruhi sisi permintaan agregat suatu perekonomian dalam jangka pendek. Selain itu, pengaruh dari kebijakan ini juga dapat dirasakan pada sisi penawaran yang sifatnya lebih berjangka panjang, misalnya melalui peningkatan kapasitas perekonomian (Surjaningsih dkk,2012).

\section{Hubungan Teoritis Pendapatan dan Pertumbuhan Ekonomi}

Dalam menganalisis masalah pertumbuhan ekonomi, teori Harrod-Domar bertujuan untuk menerangkan syarat yang harus dipenuhi supaya suatu perekonomian dapat mencapai pertumbuhan yang teguh (steadygrowth) dalam jangka panjang. Dalam teorinya, Harrod-Domar melihat persoalan pertumbuhan dari segi permintaan, yaitu menekankan pentingnya peranan akumulasi kapital dalam proses pertumbuhan. Apabila pada suatu waktu terdapat keseimbangan pendapatan pada tingkat full employment, maka untuk memelihara keseimbangan agar dapat bertahan dari tahun ketahun dibutuhkan pengeluaran investasi untuk menghisap kenaikan output yang ditimbulkan. Jadi investasi harus adas upaya keseimbangan tidak terganggu.

Model Solow menunjukkan bahwa tingkat tabungan adalah determinan penting dari persediaan modal pada kondisi steady-state. Dengan kata lain, jika tingkat tabungan tinggi, maka perekonomian akan mempunyai persediaan modal yang besar dan tingkat ouput yang tinggi, serta sebaliknya. Dasar dari model Solow inilah yang kemudian banyak dikaitkan dengan kebijakan fiskal. Defisit anggaran yang terjadi terus-menerus dapat mengurangi tabungan nasional dan menyusutkan kemampuan berinvestasi. Konsekuensi dalam jangka panjang, yakni rendahnya persediaan modal dan pendapatan nasional.

Dalam kaitannya dengan tingkat pertumbuhan, menurut Solow, tingkat tabungan yang lebih tinggi hanya akan meningkatkan pertumbuhan untuk sementara sampai perekonomian mencapai kondisi steady-state baru yang lebih tinggi dari sebelumnya. Jika perekonomian mempertahankan tingkat tabungan yang tinggi, maka hal itu hanya akan mempertahankan persediaan modal yang besar dan tingkat output yang tinggi tanpa mempertahankan tingkat pertumbuhan yang tinggi. (Mankiw, 2006)

\section{Hubungan Teoritis Pengeluaran Pemerintah dan Pertumbuhan Ekonomi}

Pengeluaran pemerintah mempengaruhi berbagai sektor dalam perekonomian. Adanya pengeluaran pemerintah secara langsung atau tidak langsung berpengaruh terhadap sektor produksi barang dan jasa. Pengeluaran pemerintah untuk pengadaan barang dan jasa akan berpengaruh secara langsung terhadap produksi barang dan jasa yang dibutuhkan pemerintah. Pengeluaran pemerintah untuk sektor pendidikan akan berpengaruh secara tidak langsung terhadap perekonomian, karena pendidikan akan menghasilkan SDM yang lebih berkualitas dan pada akhirnya akan meningkatkan produksi. 
Jurnal Progres Ekonomi Pembangunan (JPEP)

Volume 5, Nomor 1. Tahun 2020

Page: $1-11$

http://ojs.uho.ac.id/index.php/JPEP

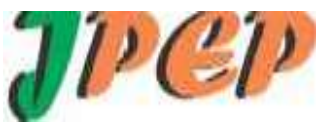

Paham Keynesian menyatakan bahwa pertumbuhan pendapatan nasional ditentukan olehbesarnya pengeluaran konsumsi, pengeluaran pemerintah, investasi dan net ekspor. Menurut Keynes untuk meningkatkan pertumbuhan ekonomi yang diukur pada peningkatanpendapatan nasional, diperlukan peningkatan permintaan konsumsi, permintaan pengeluaranpemerintah, permintaan investasi, serta permintaan ekspor dan impor. Konsep perhitungan pendapatan nasional dengan pendekatan pengeluaran menyatakan bahwa: $\mathrm{Y}=\mathrm{C}+\mathrm{I}+\mathrm{G}+\mathrm{X}-\mathrm{M}$.

Persamaan ini dikenal sebagai persamaan identitas pendapatan nasional, dimana $\mathrm{Y}$ adalahpendapatan nasional sekaligus sebagai penawaran agregat, $G$ menyatakan pengeluaranpemerintah, I menyatakan investasi, X-M adalah net ekspor. Dengan membandingkan nilai Gterhadap Y serta mengamatinya dari waktu ke waktu dapat diketahui seberapa besarkontribusi pengeluaran pemerintah dalam pembentukan pendapatan nasional.

Ekonom lain, Adolf Wagner, menyatakan bahwa pengeluaran pemerintah dan kegiatanpemerintah semakin lama semakin meningkat. Wagner mengukur perbandingan pengeluaranpemerintah terhadap produk nasional negara-negara Eropa, Amerika Serikat dan Jepang padaabad ke-19. Hasilnya terbukti menunjukkan bahwa aktivitas pemerintah dalam perekonomianmengalami kecenderungan yang semakin meningkat. Kecenderungan ini oleh Wagner disebutdengan hukum selalu meningkatnya peranan pemerintah (law of ever increasing state activity) (Mangkoesoebroto, 2011).

\section{Hubungan Teoritis Pembiayaan Defisit Anggaran dan Pertumbuhan Ekonomi}

Anggaran sebagai kebijakan pemerintahuntuk membuat pengeluran pemerintah lebih besar dari pemasukkan negara guna memberi stimulus pada perekonomian(Rahayu, 2014).Dalam hal penerimaan pemerintah terutama dari pajak tidak cukup untuk menutupi pengeluarannya, pemerintah dapat menutupinya melalui pinjaman (borrow) (Dornbusch dan Fisher (2004).Beberapa alternatif untuk menutupi beberapa pengurangan pengeluaran melalui beberapa tindakan seperti : membatasi konsumsi dan investasi yang tidak produktif, peningkatan tarif pajak yang ada, penerapan pajak baru, surplus dari perusahaan negara, pinjaman pemerintah.

Penggunaan utang untuk membiayai pembangunan dapat juga dianalisis dengan menggunakan teori tarikan pinjaman (Loan PullTheory) dan teori desakan pinjaman (Loan PushTheory).Teori tarikan pinjaman (Loan PullTheory) dipelopori oleh Hallberg (1989).

Pada umumnya pinjaman luar negeri pemerintah tergantung pada besarnya kebutuhan untuk pembiayaan pembangunan dan ketersediaan tabungan didomestik (saving investment gap) dan kebutuhan untuk membiayai kesenjangan antar ekspor dan impor (foreign exchange gap).Pinjaman luar negeri pemerintah dapat pula dilihat dari desakan pinjaman (loan push).Teori ini dikemukakan oleh Rosenstein-Rodan.Menurut teori ini bahwa untuk menanggulangi hambatan pembangunan ekonomi negara terbelakang dan untuk mendorong ekonomi negara tersebut ke arah kemajuan diperlukan suatu dorongan kuat (big push) atau suatu program besar yang menyeluruh dalam bentuk suatu jumlah minimum investasi (Jhingan, 2003).

\section{Kerangka Konsep}

Fokus penelitian ini adalah untuk menganalisisdampak dari kebijakan fiskal dan kebijakan moneter terhadap pertumbuhann ekonomi di Indonesia.Dimana variabelbebas dalam penelitian ini 
Jurnal Progres Ekonomi Pembangunan (JPEP)

Volume 5, Nomor 1. Tahun 2020

Page: $1-11$

http://ojs.uho.ac.id/index.php/JPEP

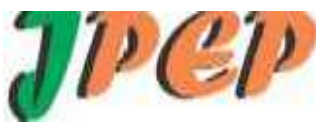

adalah Kebijakan Fiskal dan Kebijakan Moneter serta Pertumbuhan Ekonomi sebagai variabel terikat. Sehingga dapat dirumuskan kerangka konsep sebagai berikut:

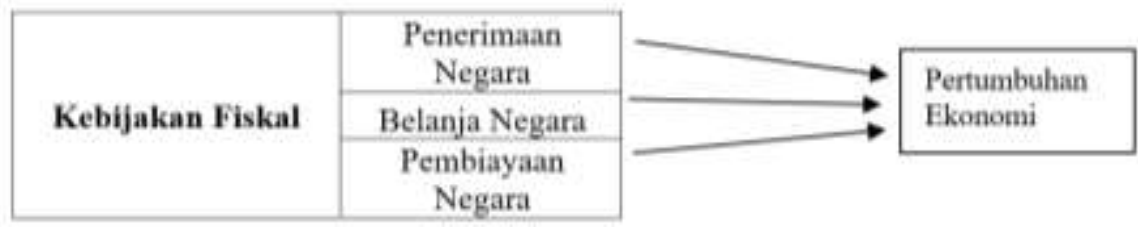

Gambar 3.1. Skema Kerangka Konsep

\section{METODE PENELITIAN}

Jenis Penelitian ini adalah Penelitian Ekplanasi (explanatory research) yaitu Penelitian yang bertujuan untuk menguji atau menjelaskan pengaruh antara variable yang dihipotesiskan.

Variabel dalam penelitian ini terdiri dari variabel bebas dan variabel terikat.Dimana variabel bebas dalam penelitian ini adalah kebijakan fiskal yang diukur melalui penerimaan negara, belanja negara, dan pembiyaan sedangkan varibel terikatnya adalah pertumbuhan ekonomi.

Metode analisis yang digunakan dalam penelitian ini adalah analisis kulitatif dan metode analisis kuantitatif. Dan sesuai dengan sifat masalah yang di ajukan, secara kuantitatif bentuk model pendekatan/persamaan ekonometrika yang digunakan untuk menganalisis hasil penelitian ini yaitu model persamaan Error Corecction Model (ECM), dalam proses pengolahan data dengan pendekatan ECM ini, ada beberapa tahap yang harus dilalui. Tahapan itu antara lain; uji stasioneritas, uji kointegrasi dan uji ECM.

\section{Uji Stasioneritas ( Uji Akar Unit )}

Uji stasioneritas akar unit (unit root test) merupakan uji yang pertama harus dilakukan sebelum melakukan analisis regresi dari data yang dipakai.Tujuan uji stasioneritas adalah untuk melihat apakah rata-rata varians data konstan sepanjang waktu dan kovarian antara dua atau lebih data runtun waktu hanya tergantung pada kelambanan antara dua atau lebih periode waktu tersebut.

\section{Penentuan Nilai Lag Optimum}

Penentuan panjang pendeknya lag adalah salah satu bagian yang penting dari pemodelan. Berbagai kriteria seleksi untuk menilik panjang pendeknya lag seperti Akaike Information Criterion (AIC), Schwarz's Information Criterion (SC), Hannan and Quinn Information (HQ), dan Final Prediction Error (FPE) telah diusulkan dalam berbagai literatur ekonometrika. Lag yangterlalu panjang dapat menambah derajat kesalahan dalam peramalan. Sebaliknya, terlalu sedikit lag bisajadi mengeluarkan informasi yang relevan.

\section{Uji Kointegrasi}

Setelah mengetahui bahwa data series telah stasioner, makalangkah selanjutnya adalah melakukan identifikasi apakah datater kointegrasi. Untuk itu diperlukan uji kointegrasi. Uji kointegrasi digunakan untuk memberi indikasi awal bahwamodelyang digunakan memiliki hubungan jangka panjang (cointegration relation). 
Jurnal Progres Ekonomi Pembangunan (JPEP)

Volume 5, Nomor 1. Tahun 2020

Page: $1-11$

http://ojs.uho.ac.id/index.php/JPEP

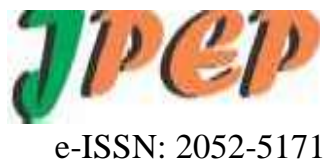

Dalam melakukan uji kointegrasi harus diyakini terlebih dahulu bahwa variabel-variabel terkait dalam pendekatan ini memiliki derajat integrasi yang sama atau tidak (Insukindro, 1992).

\section{Uji ErrorCorrectionModel}

Apabila lolos dari uji kointegrasi, selanjutnya akan diuji dengan menggungkan model linier dinamis untuk mengetahui kemungkinan terjadinya perubahan struktural, sebab hubungan keseimbangan jangka panjang antara variabel bebas dan variabel terikat dari hasil uji kointegrasi tidak akan berlaku setiap saat. Secara singkat, proses bekerjanya ECM pada persamaan pertumbuhan ekonomi yang telah dimodifikasi menjadi:

$$
\Delta \mathrm{Y}_{\mathrm{t}}=\mathrm{a} 0+\mathrm{a} 1 \Delta \mathrm{GREV}_{\mathrm{t}}+\mathrm{a} 2 \Delta \mathrm{GEXP}_{\mathrm{t}}+\mathrm{a}_{3} \Delta \mathrm{P}_{\mathrm{t}}++\mathrm{a} 4 \mathrm{e}_{\mathrm{t}}-1+e_{\mathrm{t}}
$$

\section{HASIL PENELITIAN DAN PEMBAHASAN}

Sebelum penurunan model ECM dilakukan, terlebih dahulu dilakukan beberapa tahapan pengujian yang harus dilalui seperti uji stasioner, uji derajat integrasi dan uji kointegrasi sebagai berikut:

\section{Hasil Uji Stasioner}

Tabel.1

Hasil uji Tingkat First Difference

\begin{tabular}{clccc}
\hline \hline Series & Prob. & Keterangan & Max Lag & Obs \\
\hline D(GREV) & 0.0000 & Stasioner & 9 & 36 \\
D(GEXP) & 0.0002 & Stasioner & 9 & 36 \\
D(P) & 0.0000 & Stasioner & 9 & 38 \\
\hline \hline
\end{tabular}

Sumber: Hasil Olahan

Dari tabel diatas, dapat disimpulkan bahwa data yang digunakan dalam penelitian ini sudah stationer pada tingkat first difference.

\section{Hasil Uji Lag}

Sebuah kebijakan ekonomi seperti kebijakan fiskal biasanya tidak secara langsung berdampak pada aktivitas ekonomi tetapi memerlukan waktu (lag). Penentuan panjang lag optimal merupakan hal yang sangat penting dalam ECM, yang berguna untuk menangkap semua pengaruh dari variabel-variabel bebas.Penentuan panjang lag optimal digunakan untuk mengetahui seberapa banyak lag yang digunakan dalam estimasi ECM. Kriteria yang umum digunakan dalam menentukan panjang lag optimal adalah Akaike Information Criteria (AIC) dan Schwarz Information Criteria (SIC). 
Jurnal Progres Ekonomi Pembangunan (JPEP)

Volume 5, Nomor 1. Tahun 2020

Page: $1-11$

http://ojs.uho.ac.id/index.php/JPEP

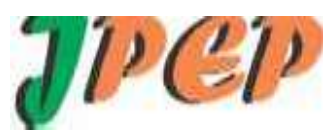

Tabel. 2

Hasil uji Derajat Integrasi Tingkat First Difference

\begin{tabular}{crccccc}
\hline \hline Lag & LogL & LR & FPE & AIC & SC & HQ \\
\hline \hline 0 & -75.46335 & NA & $1.26 \mathrm{e}-08$ & 4.511532 & 4.859839 & 4.634327 \\
1 & 54.39808 & 196.5470 & $3.87 \mathrm{e}-10$ & 0.951455 & $4.086214^{*}$ & 2.056605 \\
2 & 158.0793 & $112.0878^{*}$ & $7.59 \mathrm{e}-11$ & -1.193475 & 4.727737 & 0.894029 \\
3 & 257.4912 & 64.48338 & $6.33 \mathrm{e}-11^{*}$ & $-3.107631^{*}$ & 5.600034 & $-0.037771^{*}$ \\
\hline \hline
\end{tabular}

Sumber: Hasil Olahan

Berdasarkan Tabel 2 lag yang optimal menurut kriteria SIC dan adalah lag 1 dan LR adalah 2. Sementara, jika menggunakan kriteria FPE, AIC dan GQ lag yang optimal adalah lag 3. Merujuk pada kelima kriteria tersebut, nilai lag optimal adalah pada lag 3. Maknanya adalah kebijakan fiskal akan berdampak langsung pada pertumbuhan ekonomi pada bulan ke sembilan ( $3 \times 3$ bulan).

\section{Hasil Uji Kointegrasi}

Pengujian ini dilakukan untuk mengetahui apakah dalam jangka panjang terdapat hubunganantara variabel independen dengan variabel dependennya (cointegrastion relation). Hal pertama yang dilakukan pada uji kointegrasi adalah dengan melihat apakah residualdari hasil output estimasi model diatas yang digunakan dalam penelitian telah stasioner pada levelatau tidak. Pengujian ini dengan menggunakan uji Augmented Dickey-Fuller (ADF-Test). Hasil Uji Konitegrasi adalah sebagai berikut:

Tabel. 3 Hasil uji kointegrasi dengan metode Augmented Dickey-Fuller

\begin{tabular}{ccccc}
\hline \hline Variable & Coefficient & Std. Error & t-Statistic & Prob. \\
\hline \hline RES (-1) & -0.482271 & 0.142411 & -3.386470 & 0.0017 \\
C & -0.001813 & 0.009171 & -0.197737 & 0.8443 \\
\hline \hline
\end{tabular}

Sumber: Hasil Olahan

Dikatakan variabel-variabelnya terkointegrasi ketika nilai probabilitas statistik residualnya itu kurang dari 5 persen, dan koefisiennya negatif. Berdasarkan nilai pada tabel 4.3.terlihat bahwa nilai probabilitasnya sebesar 0.0017 lebih kecil dari 5 persen dan nilai koefisien -0.482271 maknanya analisis selanjutnya bisa dilanjutkan.

\section{Hasil Estimasi Jangka Pendek}

Uji stasioneritas data dan uji kointegrasi telah dilakukan, hasilnya menunjukkan bahwa data penelitian tidak stasioner pada level dan stasioner pada diferensiasi tingkat pertama serta beberapa variabel terkiontegrasi. Adanya kointegrasi tersebut menunjukkan bahwa ada hubungan atau keseimbangan jangka panjang pada variabel tersebut. 
Jurnal Progres Ekonomi Pembangunan (JPEP)

Volume 5, Nomor 1. Tahun 2020

Page: $1-11$

http://ojs.uho.ac.id/index.php/JPEP

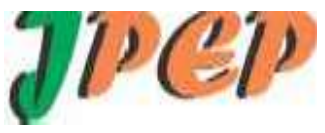

Atas dasar inilah maka model koreksi kesalahan (ECM) digunakan untuk mendeteksi seberapa besar dan cepat penyesuaian jangka pendek antar variabel yang terkointegrasi menuju kondisi keseimbangan kembali. Dan berikut ini hasil uji Error Correction Model (ECM).

Tabel.4.

Hasil Estimasi Jangka Pendek Pengaruh Fiskal Terhadap Pertumbuhan Ekonomi Indonesia

\begin{tabular}{ccccc}
\hline \hline Variable & Coefficient & Std. Error & t-Statistic & Prob. \\
\hline C & 0.806092 & 0.098102 & 8.216917 & 0.0000 \\
D(GREV) & 0.087105 & 0.026215 & 3.322778 & 0.0024 \\
D(GEXP) & 0.017570 & 0.003920 & 4.481611 & 0.0001 \\
D(P) & 0.005761 & 0.003302 & 1.744821 & 0.0913 \\
RESID-1 & 0.807018 & 0.098175 & 8.220197 & 0.0000 \\
\hline \hline \multirow{2}{*}{ R-squared } & 0.821683 F-statistic & & 17.27994 \\
Adjusted R-squared & 0.774132 Prob(F-statistic) & & 0.000000 \\
\hline \hline
\end{tabular}

Sumber: Hasil Olahan

Berdasarkan hasil analisis menunjukkan bahwa dalam jangka pendek, hanya variabel pembiayaan yang secara statistik tidak signifikan mempengaruhi pertumbuhan ekonomi. Hal ini dapat dilihat dari hasil estimasi seperti ditunjukkan pada tabel.4. Hasil uji koreksi kesalahan model (ECM) pada tabel 4.4 terlihat bahwa nilai residual (0.0807018), dan nilai probabilitas dibawah 5 persen, hal ini menunjukkan bahwa koreksi kesalahan adalah sebesar 8.07 persen yang akan disesuaikan (adjusment) dalam 3 bulan sehingga terjadi keseimbangan (equilibirium) dalam jangka pendek.

\section{Hasil Estimasi Jangka Panjang}

Dalam jangka panjang variabel yang secara signifikan mempengaruhi pertumbuhuan ekonomi adalah variabel GREV dan GEXP hal ini ditunjukkan dengan nilai probabilitas lebih besar dari $\alpha$ 5\% Secara statistik dapat dilihat pada tabel estimasi jangka panjang berikut ini.

Tabel.5.

Hasil Estimasi Regresi Jangka Panjang Pengaruh Kebijakan Fiskal Terhadap Pertumbuhan Ekonomi Indonesia (pada $\alpha=0,05$ )

\begin{tabular}{ccccc}
\hline \hline Variable & Coefficient & Std. Error & t-Statistic & Prob. \\
\hline \hline C & 1.083848 & 0.148595 & -7.293961 & 0.0000 \\
GREV & 0.012470 & 0.004739 & 2.645837 & 0.0125 \\
GEXP & 0.002991 & 0.001131 & 2.631291 & 0.0130 \\
P & 0.000815 & 0.001033 & 0.789174 & 0.4358 \\
\hline \hline R-squared & 0.758523 F-statistic & & 14.35970 \\
Adjusted R-squared & 0.705700 Prob(F-statistic) & & 0.000000 \\
\hline \hline
\end{tabular}

Sumber : Hasil Olahan 
Jurnal Progres Ekonomi Pembangunan (JPEP)

Volume 5, Nomor 1. Tahun 2020

Page: $1-11$

http://ojs.uho.ac.id/index.php/JPEP

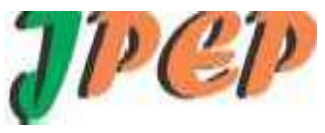

Dari hasil perhitungan regresi pada tabel 5, diperoleh nilai koefisien persamaan regresi jangka panjang yang dapat dituliskan sebagai berikut:

$\mathrm{Y}=-1.083848++0.012470(\mathrm{GREV})+0.002991(\mathrm{GEXP})+0.000815(\mathrm{P})$

Berdasarkan hasil analisis regresi di atas, menunjukkan bahwa secara umum variabel dari kebijakan fiskal mempunyai hubungan yang positif terhadap pertumbuhan ekonomi Indonesia dalam jangka panjang. Dari hasil analisis tersebut menunjukkan bahwa dalam jangka panjang kebijakan fiskal secara simultan mempunyai pengaruh terhadap pertumbuhan ekonomi Indonesia. Hasil ini dapat dilihat dari niali uji $\mathrm{F}$ yang mempunyai nilai $\mathrm{F}$ (prob) sebesar 0.000000 lebih kecil dari $\alpha 5$ persen.

Dari hasil pengujian diperoleh nilai Adjusted R-squaredsebesar 0,705 menunjukkan bahwa kemampuan model dalam penelitian ini untuk menjelaskan variabel pertumbuhan ekonomi Indonesia sebesar 70,5 persen, sisanya sebesar 29,5 persen ditentukan oleh variabel lain diluar model yang turut mempengaruhi pertumbuhan ekonomi.

Secara parsial arah hubungan variabel penerimaan negara terhadap variabel pertumbuhan ekonomi bersifat positif dengan nilai koefisien 0.012. Jika penerimaan naik maka pertumbuhan ekonomi negara juga akan naik. Ini memberikan isyarat bahwa pendapatan negara mempunyai peranan penting dalam mendukung aktivitas perekonomian nasional, seperti untuk membiayai pelaksanaan kegiatan pemerintah dan pembangunan guna mencapai pertumbuhan ekonomi dan meningkatkan pendapatan nasional.Hasil penelitian ini mempertegasteori Harrod - Domar yang menyatakan bahwa pentingnya pembentukan modal sebagai syarat utama untuk mencapai pertumbuhan ekonomi yang baik (steady growth).

Berdasarkan hasil etimasi pada tabel 4.5, nilai koefisien regresi variabel belanja negara terhadap pertumbuhan ekonomisebesar 0.012 dan mempunyai hubungan yang positif. Memberikan makna jika belanja negara naik maka pertumbuhan ekonomi juga akan naik. Hal ini dikarenakan pengeluran pemerintah merupakan salah satu komponen dalam permintan agregat (aggregate demand), apabila pengeluaran pemerintah meningkat maka permintaan agregat akan meningkat yang pada akhirnya mendorong pengusaha/pelaku ekonomi untuk meningkatkan produksinya guna memenuhi peningkatkan permintaan barang/jasa. Selain itu peranan pengeluaran pemerintah sangat penting dalam perekonomian, mengingat kemampuan sektor swasta untuk mendorong pertumbuhan ekonomi masih sangat terbatas. Peningkatan permintaan berarti terjadi pertumbuhan ekonomi, karena pertumbuhan ekonomi di ukur dari produk domestik bruto.

Hasil estimasi dari tabel 4.5 diatas, terlihat bahwa pembiayaan dalam APBN (P) mempengaruhi pertumbuhan ekonomi Indonesia dan besar pengaruhnya sebesar 0.0008. Apabila dilihat dari arah hubungan antara pembiayaan anggaran terhadap pertumbuhan ekonomi bersifat positif. Hal tersebut menunjukkan bahwa fungsi pembiayaan anggaran mempunyai peran penting terhadap fluktuasi pertumbuhan ekonomi melalui konsep kebijakan fiskal ekspansif.

Ketika pendapatan negara terutama dari pajak sangat terbatas, maka dampaknya kebijakan fiskal untuk ekspansif dalam mendukung pertumbuhan ekonomi relatif kecil.Hal inilah yang menyebabkan meningkatnya pembiayaan defisit yang bersumber dari utang, baik daridalam negeri maupun dari luar negeri.Sifat hubungan antara kebijakan fiskal ekspansif dan defisit pembiayaan dengan metode utang adalah positif, menunjukkan bahwa sepanjang pemerintah masih menerapkan 
Jurnal Progres Ekonomi Pembangunan (JPEP)

Volume 5, Nomor 1. Tahun 2020

Page: $1-11$

http://ojs.uho.ac.id/index.php/JPEP

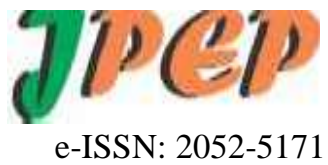

kebijakan fiskal yang ekspansif (pengeluaran pemerintah melebihi penerimaannya), utang masih akan terus meningkat

Hasil penelitian ini sesuai dengan teori yang ada seperti teoriHarrod-Domar, kesenjangan antara tabungan dan investasi (investment and saving) dan juga kesenjangan antara penerimaan dan pengeluaran (two gap model theory), serta beberapa teoripembentukan modal lainnya sepertiLoan Pull Theoryyang dipelopori oleh Hallberg. Dasar teori ini bahwa pinjaman luar negeri yang dilakukan oleh pemerintah dilandasi oleh perhitungan yang matang terkait dengan peningkatan kapasitas produksi nasional. Dengan kata lain, proyek-proyek yang dibiayai dengan pinjaman luar negeri akan menimbulkan kapasitas pembayaran kembali (repayment capacity) terhadap pinjaman luar negeri yang membiayainya. Kemudian Loan Big PushTheoryyang dipelopori oleh Rosenstein-Rodan menyatakan bahwa untuk menanggulangi hambatan pembangunan ekonomi negara terbelakang dan untuk mendorong ekonomi negara tersebut diperlukan dorongan yang kuat (big push) atau suatu program yang besar yang menyeluruh dalam bentuk suatu jumlah minimum investasi

\section{KESIMPULAN DAN SARAN}

\section{Kesimpulan}

Berdasarkan hasil penelitian dan pembahasan yang telah diuraikan pada bab sebelumnya, maka penulis menarik suatu kesimpulan bawa kebjikan fiskal dan kebijakan moneter berpengaruh secara signifikan terhadap pertumbuhan ekonomi Indonesia baik dalam jangka pendek maupun dalam jangka panjang.

\section{Saran}

Dari hasil analisis penelitian, variabel peneriman negara yang paling dominan dalam mempengaruhi pertumbuhan ekonomi Indonesia. Oleh karena itu kiranya pemerintahlebih memaksimalkan potensi sumber-sumber penerimaan negara baik dari sektor pajak maupun sektor non pajak.

\section{DAFTAR PUSTAKA}

Bank Indonesia, Statistik Ekonomi dan Keuangan Indonesia. Berbagai Edisi

Badan Pusat Statistik. Laporan Perekonomian. Berbagai Edisi

Belliveau, Stefan. (2011).A St. Louis Equation to Reasses The Influence of Macroeconomic-Policy Intrument. Munich personal RePec Archiv paper No.28771.

Dornbusch, Rudiger. (2004). Makro Ekonomi . Edisi bahasa Indonesia. PT. Media Global Edukasi, Jakarta.

Gulo, Angandrowa. (2008). Analisis Pengaruh Aspek Kebijakan Fiskal dan Moneter Terhadap Pertumbuhan Ekonomi. Tesis. Universitas Sumatera Utara.

Hoppner, Florian. (2011). A VAR Analysis of the Effect of Fiscal Policy in Germany. Institute for International Economics, University of Bonn.

Insukindro. (1992). Pembentukan Model Dalam Penelitian Ekononmi" Jurnal Ekonomi Dan Bisnis Indonesia no. 1 TahunVII .Yogyakarta

Irfan. (2015). Kebijakan Moneter dan Pertumbuhan Ekonomi Indonesia.Jurnal Akuntansi dan Pembangunan, Vol, 1. 
Jurnal Progres Ekonomi Pembangunan (JPEP)

Volume 5, Nomor 1. Tahun 2020

Page: $1-11$

http://ojs.uho.ac.id/index.php/JPEP

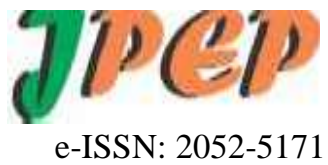

Jhingan, M. L.(2003). Ekonomi pembangunan dan perencanaan, Jakarta : PT. RajaGrafindo Persada. Mankiw, Gregory N. (2006). Pengantar Ekonomi Makro. Jakarta: Ghalia Indonesia.

Mangkoesoebroto, Guritno.(2011).Ekonomi Publik Edisi 3. Penerbit BPFE, Yogyakarta.

Nainggolan, Benny RM. (2010). Interaksi Kebijakan Fiskal dan Moneter di Indonesia Terhadap Variabel Ekonomi Makro di Indonesia, Medan: Universitas Sumatera Utara.

Nawawi, Ahmad dan Irawan, Ferry.(2011). Analisis Dampak Kebijakan Fiskal terhadap pertumbuhan Ekonomi di Indonesia.Jurnal Ekonomi Pembangunan Vol.10.

Olisaemeka, Lawrence. (2018). Effect Of Monetary Policy On Economic Growth In Nigeria An Empirical Investigation. ISSN : 2393-1975 Issue 1/2018.

Rahayu, Ani Sri. (2014). Pengantar Kebijakan Fiskal. Jakarta: Bumi Aksara.

Rantebua, Sem. (2019) Analisis bauran Kebijakan Fiskal dan Kebijakan Moneter Terhadap Pertumbuhan Ekonomi Indonesia, Kendari. Universitas Haluoleo.

Santoso,Teguh dan Basuki, Maruto Umar. (2009). Dampak Kebijakan Fiskal dan Moneter dalam Perekeonomian Indonesia .Jurnal Organisasi dan Management.

Sukirno, Sadono. 2004. Makro Ekonomi Teori Pengantar. Edisi III. Jakarta: PT Raja Grafindo Persada.

Surjaningsih, Ndari. dkk. 2012. Dampak Kebijakan Fiskal Terhadap Output dan Inflasi. Jakarta : BI, Buletin Ekonomi Moneter dan Perbankan.

Topcu, Mert and Ayhan Kuloglu. (2012). "Total Spending Equation of St. Louis Model: A Causality Analysis for Turkish Economy". Chinese Business Review, Vol. 11, No. 4.

Waluyo, Joko. (2006). Pengaruh Pembiayaan Defisit Anggaran Terhadap Inflasi dan Pertumbuhan Ekonomi. Yogyakarta: UPN. 